\title{
Saul Bellow and Wilhelm Reich
}

By

Helge Normann Nilsen

University of Trondheim

Wilhelm Reich, famous psychotherapist, socialist and eccentric scientist of the mysterious orgone energy, was a thinker whose work has influenced Saul Bellow very strongly, particularly during that period in the author's life when he wrote Seize the Day (1957) and Henderson the Rain King (1959). Bellow's indebtedness to Reich has not gone unnoticed among students of the novelist's work. Eusebio L. Rodrigues has traced the influence of several of Reich's theories in Henderson, claiming that the novel shows the "complete therapeutic transformation" of Henderson himself. ${ }^{1}$ Paul Clayton has commented on the incorporation of Reichian ideas in Seize the Day and states that Tommy Wilhelm's breakdown at the end of the story represents "a healing surrender of the armored self." 2 In his analysis of Henderson, M. Gilbert Porter speaks of the protagonist as "the fully regenerate Henderson joyously celebrating the new life that he has discovered."'3 These critics seem to believe that Bellow subscribes to the validity of Reichian doctrine and that he presents his characters in the process of undergoing a genuine therapeutic change. However, Bellow's attitude is much more complex than that, and the purpose of this essay is to show that his treatment of Reichianism in Seize the Day and Henderson the Rain King is chiefly ironic and comic, although he also shows a degree of ambivalence toward the whole subject.

The aim of therapy for the neuroses, as Reich saw it, was to liberate the patient from his defense system, which was located in the body itself, in the so-called "muscular armor." Freudian analysis had primarily concerned itself with verbal insights, but Reich took the method one step further and aimed straight at the bodily postures and movements in his "vegetotherapy." He also wrote numerous books and articles on a variety of subjects and conducted laboratory experiments in search of the orgone energy which he 
regarded as a cosmic force. His theory of neurosis as a social and individual phenomenon is amply outlined in such works as The Mass Psychology of Fascism, The Function of the Orgasm and Character Analysis.

Reich's view of modern man and his emotional condition is a very dramatic one, and the whole tenor of his writings is passionate and prophetic. He denounces modern bourgeois society as a system which oppresses people not only economically and politically, but emotionally as well. From the moment of birth, the person is forced into a Procrustean bed of sexual and other taboos and strictures which threaten to destroy his soul and emotional well-being. The result is neurosis, which Reich regarded as a mass phenomenon. More especially, the result is what he called "character neurosis." The pursuit of money and power leads to the formation of character neurotics on a large scale, and in order to solve the problem one has to change the entire economic and social structure as well as the emotional structure of the people who are part of the system. It was to further these goals that Reich developed his "character-analytic vegetotherapy," by means of which the therapist seeks to loosen up the patient's "muscular armor" and bring his repressed emotions to the surface, thus restoring his real self and his psychological health to $\operatorname{him}^{5}$

Bellow has translated Reich's medical and psychiatric categories into more general and literary terms in his fiction, and in Seize the Day he has defined his social criticism within a Marxist and Reichian context, seeing the problems of the protagonist as an expression of a rebellious attitude towards the sickness of a competitive, moneyworshipping society. The false ideals of this society oppress people in their very bodies, and Bellow shows us a protagonist who feels suffocated by his environment. Seize the Day describes a crisis in Tommy's life, a point at which all his problems threaten to submerge him. He tries to get help from his father, understanding from his estranged wife and money from stock market speculations, but these all turn out to be false starts, blind alleys. His need is to rediscover his natural self, break through to his basic emotions and thus reclaim his psychological health. But this means that he must loosen up his muscular armor, and he is not ready to do that until at the end, when he sees no way out at all. Meanwhile, he suffers from the tensions of the armor, as in the scene where he pleads for support from his father in the dining room of the Hotel Gloriana, feeling that he has "a great knot of wrong tied tight within his chest." 6 
Meanwhile, Dr. Tamkin, a curious charlatan-healer figure, makes his appearance and begins instructing Tommy in the truths of the Reichian world-view, the critique of the mass neurosis of bourgeois capitalism: "Every public figure had a character neurosis. Maddest of all were the businessmen, the heartless, flaunting, boisterous business class who ruled this country with their hard manners and their bold lies and their absurd words that nobody could believe. They were crazier than anyone. They spread the plague" (86). The business class, which adheres to the Protestant work ethic and the capitalist value system, has developed characters who are neurotic structures. In other words, the neurosis is not partial, it is total.' The result of it is a suppression of all natural instincts, of the freely flowing orgone energy that Reich regarded as the basis of emotional well-being, and the encroachment of what he regarded as "the emotional plague" deplored by Tamkin. The essence of the emotional plague is stiffness, rigidity, being devoted to power, money, the future, everything except the present moment, the life of sensation and feeling.

To live spontaneously, to enjoy the moment, would mean dissolving the stiffness of the character armor. Thus, when Tamkin exhorts Tommy to "seize the day," his advice bears a specific Reichian meaning. This also applies to the doctrine of the pretender soul and the real soul which he explains to Wilhelrn: "The interest of the pretender soul is the same as the interest of the social life, the society mechanism. This is the main tragedy of human life" (96). Tamkin, in true Reichian fashion, identifies the pretender soul, the character armor, with society and its norms, chiefiy its devotion to power and money, and advocates the rights of the real soul, which clamors for truth and love. In an elegantly ironic handling of the plot, Bellow has Tamkin giving bad advice to Tommy about how to invest his money so that he iooses it all and thus is prepared for a more spiritual sort of existence.

Seize the Day describes a process which resembles vegetotherapy without a professional therapist, and it culminates in the scene at the end where Tommy breaks down at the funeral of a stranger, releasing his basic feelings of grief and sorrow, but the meaning of the story goes beyond that level. There is a thread of ironic comment throughout the text which shows Bellow's reservations about the gospel of Reich. This is evident both in the rendering of Tommy's immaturity and gullibility and in the very dubious impression which Tamkin makes upon any reader. He is presented as a con- 
man, one who has "deceiver's brown eyes" and is a "confuser of the imagination." Moreover, he is obviously a fraud, an amateur and a fantasizer. His theories and case histories are a mixture of extravagant improbabilities and genuine insight. Tommy sees him as a person of "one hundred falsehoods, but at least one truth." To some extent, Tamkin is a parody on Reich himself, who undertook quite a few extravagant projects during the last phase of his career, such as the invention of cancer cures and rain-making machines. Reich's theories about rain-making have been worked into Henderson the Rain King, in which the protagonist's ritual exercises release amounts of energy that seem to be the cause of the rainfall that the Wariri tribe has been trying to bring about.

In Seize the Day Bellow's treatment of Reichianism is a unique blend of comedy and pathos which reflects the author's complex view of Tommy Wilhelm, buffoon and sufferer, and Dr. Tamkin, his would-be savior and quack. The social criticism of Reich, with its powerful combination of marxism and psychotherapeutic analysis, supplied Bellow with a theoretical framework for the expression of his own disillusionment with a society obsessed with financial gain and careerism. But however victimized, his suffering and protesting protagonist is just as amusing as he is pathetic, and it is quite clear that his problems are very largely of his own making. The vicissitudes of Tommy Wilhelm form a comic tale of urban life, and it is clear that his "therapeutic" release at the end cannot be a real "solution" to his problems. These are real enough, and intractable, and the Reichian "redemption" that he experiences must necessarily be short-lived and transient.

In Henderson the Rain King, several aspects of Reichianism are dealt with extensively: the theory of neurosis, the characteranalytic therapy and the observations of the workings of the orgone energy in man as well as in nature itself. However, the social dimension of Reich's diagnosis, which was an important part of the meaning of Seize the Day, was largely left behind by Bellow when he set out to write the more individualistic and expansive novel about Eugene H. Henderson's journey to Africa. Unlike Tommy Wilhelm, Henderson is not described in terms of his relationship to any urban, social setting; most of the novel about him takes place in Africa, where he is given both space and opportunity to develop and explore himself in a series of curious and barbaric encounters and rites amongst native tribes. But beneath the trappings of the exotic plot the stages of a Reichian therapeutic process are clearly discernible. 
The opening of the novel presents a protagonist in crisis, full of confusion, existential anguish and desperately in search of answers and solutions. Like Tommy Wilhelm and Moses Herzog of Herzog (1961), he is the hero with innumerable problems, most of them of his own making. But more than any other Bellow character, he takes a perverse delight in his own chaos, indulging in a feeling that the absurdity of his condition is somehow grander than the petty follies of most men. As a literary creation, he is cast on a large scale, endowed with wealth, volcanic emotions, acute sensibilities and insatiable cravings: "When I think of my condition at the age of fifty-five when I bought the ticket, all is grief. The facts begin to crowd me and soon I get a pressure in the chest. A disorderly rush begins - my parents, my wives, my girls, my children, my farm, my animals, my habits, my money, my music lessons, my drunkenness, my prejudices, my brutality, my teeth, my face, my soul!"'s The pressure in the chest, as we have seen, indicates the plight of a neurotically armored self, an individual who cannot control his energy and thus is in danger of destroying both himself and others. In fact, an old spinster, Miss Lenox, who lives across the road from Henderson, dies from a heart attack on overhearing one his of rages.

Large parts of the first half of the novel are devoted to descriptions of the grotesque, aggressive and desperate dimensions of Henderson's personality, in short, of the "emotional plague." As Reich saw it, this condition is a deadly one, creating madness, disease, war and death, and Henderson is duly warned by a symbol of death in the shape of an octopus in an aquarium in the south of France. The eyes of the animal are cold, its head moves with a "Brownian motion," and the "cosmic coldness" of this monster suggests to Henderson that death is giving him notice. In other words, unless he changes his destructive ways, the death-in-life of neurotic confusion is what is in store for him. The reference to Brownian movements, not mentioned by Rodrigues in his study of Reichianism in the novel, stems from Reich's theory of bions, or energy vesicles. Reich believed that he had discovered the basic particles of life and that he was able to create such particles. His critics contended that the movements he observed were the well-known Brownian molecular movements which in no way indicate organic life, but only certain motions of inorganic matter. One of Reich's pupils and supporters, Ola Raknes, states: "But whoever has seen vesicular movements under a microscope and had the occasion to compare them with Brownian vesicular movements will hardly have any difficulty in 
seeing that the Brownian are angular and mechanical, while the vesicular are softer and organic."9 According to Raknes, the results of Reich's experiments along these lines were first published in the book Die Bione (Oslo, 1938). This is not the place to discuss the scientific validity of Reich's theories of bions, but it is clear that they have been worked into Bellow's novel. Brownian movements refer to lifeless matter, the state of death which threatens Henderson unless he finds release for his organic life energy.

Henderson's journey to Africa, to tribal simplicity, is, in a sense, the traditional Romantic quest back to the original state of man, the Adamic condition of innocence which is thought to exist in the remote, unmapped parts of Africa. The "genital character," the tension-free individual envisaged by Reich, is a modern, psychiatric version of this ideal image, and Reich shares the Romantic detestation of Western civilisation and the desire for a simpler, more harmonius state of being. In order to reach this stage, Henderson must learn from the two tribes he encounters and the values they represent. These, however, are very different, the Arnewi cattle raisers very gentle and peace-loving, as well as emotionally expressive, and the Wariri tribesmen much more fierceand warlike in their behavior and outlook. This difference indicates Bellow's awareness of cultural differences that exist also among primitive peoples and suggests a criticism of any sort of Romantic simplifications about the noble savage.

The protagonist finds sympathy and even love among the Arnewi, and he begins to feel that he has gained a new lease on life. Warmed and comforted by these gentle people, he experiences a joyful ease and feels confident that he will be able to solve the problem of the frogs that pollute their drinking water. But he deludes himself, believes that he has become a differentperson when, in actual fact, his troubled psyche has hardly been touched at all. He feels "bathed in high feeling," and has visions of a nature colored in idyllic pink. However, these experiences are superficial excitations which do not indicate any real change of character, a fact which is driven home by Henderson's rash decision to kill the frogs by placing a bomb in the cistern, a technique which results in the destruction of the Arnewi water supply. This event shows Henderson as a headstrong, twentieth-century Connecticut Yankee who is as likely to bring destruction as aid in his overeager attempt to help the tribes and peoples of less developed countries. His excessive reliance on technology is a manifestation of the neurosis of his civilization. The only thing 
which makes him different from many other Americans is his desire to change, his insistence on emotional fulfillment.

After his disastrous intervention, Henderson leaves the Arnewi behind and sets out to reach another tribe, the Wariri, in a last, desperate attempt to find the answer he needs. Unlike the Arnewi, the Wariri are tough and hard; their attitude is harsh and competitive. In many respects, they are closer to American or Western values than the Arnewi, and therefore better equipped to deal with Henderson and his problems. The believe in an active search for happiness and fulfillment, and it may be noted that Reichian therapy has a dynamic, almost aggressive dimension in that it involves an attack on the patient's defenses, a "breakdown" of the muscular armor. In other words, Reich employed an active therapy which also included a certain amount of pure technique, all in an attempt to recreate the natural man. In the Wariri and their king Dahfu, who has a college education and seems to have studied psychology, Bellow has created a synthesis which is ideal from a Reichian point of view. Here, Henderson will receive the shock, the jolt he needs in order to get in touch with the repressed core of his personality. However, to follow the way of the Wariri and their king is also a hazardous and dangerous undertaking, a fact which is indicated from the very beginning of the hero's sojourn with them. They capture both him and Romilayu, his faithful guide, and put them in a hut where a dead man has been placed. This is a foreshadowing of the catastrophic end of the therapeutic rituals undertaken by Dahfu and Henderson, who quickly becomes the devoted disciple of the extravagant, learned and sensuous king. He, as well as his lioness Atti, seem to embody the tension-free, harmoniously functioning state of the genital character that vegetotherapy aims at. When Henderson meets him, he is "sumptuously at rest" on a green sofa, surrounded by women who attend to his every need. His voice is powerful and resonant, he is totally at ease with himself and the world, free to enjoy both the pleasures of the flesh and the spirit. This, at any rate, is the ideal image that Henderson has of him, and he becomes painfully aware of the contrast between himself and Dahfu: "He was extended, floating; I was contracted and cramped." Later in the novel, it becomes clear that the king is not really at peace with himself and the world and that he is involved in rather frantic and dangerous quests and strivings. Henderson's image of him is unreal, born out of his own uncertainty and confusion.

For the moment, however, Henderson jumps at the opportunity 
to sit at the feet of this dazzling master or "guru" who offers a way of pacifying his restless inner urge of "I want!" Dahfu expounds a philosophy of the natural goodness of man, asserting that "good cannot be labor and conflict." In other words, once man's core of vital energy has been freed from oppression and inhibition, he will act and think in a benevolent way. Henderson agrees to undertake a therapeutic process under the king's guidance, and the crucial stage of this process occurs when the former undertakes a number of roaring sessions in the lion's den with Dahfu and Atti the lioness. The king, speaking exactly like a Reichian therapist, explains that "I intend to loosen you up, Sungo, because you are so conrsacted," and Henderson begins to observe Atti and learn from her how to recover the natural grace, the deep respiration and sense of oneness with the body that he as a civilized Westerner has lost. In order to relax his muscular armor he is instructed to roar with all his might, scream everything out, and in his willingness to comply he fills the den "like a bass organ pipe." However, there is no suggestion that this therapeutic screaming and roaring leads to anything else than an increased intensity of awareness of his own suffering. The therapy may loosen him up, but it has little to offer beyond that point.

But Henderson is not entirely uncritical toward his master and tries to keep his options open even in the midst of the esoteric quest that he has become involved in. In the last part of the novel, the insight begins to emerge in his consciousness that the clamor of his inner voice of "I want!" may have been entirely misdirected: "I had a voice that said: I want? I want? It should have told me she wants, he wants, they want" (286). The bourgeois striving after perfection of the self must be replaced by concern for others. However, the depths of illusion that king Dahfu have sunk himself into are not yet wholly clear to Henderson, nor does he fully understand the extent to which he himself shares the king's dream of regeneration. Bur hero believes that the encounters with lions which Dahfu thinks are so important will teach him to confront death, to conquer it somehow. As he sees it, all the major tasks have now been performed except how to teach man to come to terms with death. The irony of it is that the lion cult of Dahfu actually causes him to be killed, and only then does Henderson realize what a blow death and bereavement actually is. After having taken part in the king's foolhardy plan to capture a male lion in the bush, Henderson finally understands that Dahfu's obsession with lions and his need to recapture a state of innocence and grace can lead to disaster and death. Indeed, the 
whole of his quest for increased awareness of reality now assumes the aspect of a giant delusion, a blind alley, a pursuit of an entirely imaginary condition of perfection. By a stroke of luck, Henderson survives the attempt to capture the wild lion, and when the king is killed, he realizes that unlike his own exaggerated sufferings, this is a real calamity which is neither spicy nor fascinating, but merely terrible.

Dahfu's death is the turning point of the novel, and after that everything that has gone before it is seen in a different light. Things begin to fall into place as Henderson is forced to acknowledge the true proportions of experience. The despair and sorrow he feels upon the death of a friend is much more real and poignant than the woeful contemplation of his own misery. He realizes that he had met the king too late in life, that fundamental change was impossible. Instead, he decides to implement his "service ideal," to take up the study of medicine and return to his wife and children. It is not enough to establish contact with the deep layers of the psyche, in fact, the real answer is to forget the "I want" completely and start doing something sensible and useful.

Henderson the Rain King employs paradox and irony to convey the message that the hero's quest is rooted in illusions and perversities. His many adventures and pursuits turn out to be little more than laborious diversions away from certain simple truths that should have been evident to him from the beginning. During his escape from the fateful Wariri and his long trek back to civilization, Henderson is all the time aided by his faithful helper Romilayu, whose stature as a character grows significantly toward the end of the novel and who assumes the aspect of a moral focus of the narrative. Without making any fuss about it at all, he has assisted Henderson through all his escapades and, in effect, saves his life during the final journey back. He is the living embodiment of that same service ideal which Henderson belatedly comes to acknowledge and, what is even more important in the context of the novel, he seems to be able to behave with dignity and compassion without going through any therapies at all.

It would not be right to say that Henderson's quest is a complete circle, that his efforts to change have produced no results at all. He does gain some insight, but the irony of the novel lies in the fact that this does not seem to be owing to his therapeutic efforts at all. Rather, it is the disastrous end of his teacher which creates whatever new insight Henderson can be credited with. The story of Dahfu is 
in some ways very similar to the fate of Wilhelm Reich himself. During his final years as an exile in America Reich became quite obsessed with his theories and even claimed that he was an agent of forces from outer space. Also, a somewhat esoteric cult grew up around him and his institute at Orgonon, Maine. Reich was a curious combination of genius and quack, and both Dr. Tamkin and Dahfu are described in such terms. Indeed, Bellow's treatment of psychoanalysis and the therapies derived from it, such as vegetotherapy, is always tinged with humorous scepticism. In Herzog the hero's analyst, Dr. Edwig, is described as a dupe, and Bummidge, the ridiculous protagonist of the play The Iast Analysis (1965), undertakes a hilarious project of psychoanalysing himself on closed circuit television. On the other hand, Bellow has a considerable degree of respect for and interest in both psychoanalysis and vegetotherapy. He is ambivalent about it all, and this accounts for the impression of uncertainty that the novel makes upon the reader. On the whole, the tone of the book is humorous, and it contains a great deal of pure burlesque. Henderson's strange appearance, his irreverent language and his eccentric mannerisms remain unchanged throughout the whole novel, no matter how painful or frightening his experiences become. In spite of this, the atmosphere can also become quite grave, real tragedy looms in the background of his life, but only for a moment, until Henderson the lively buffoon is back on center stage. The final pages of the novel has him petting his lion cub on the plane back to America, flirting with the stewardess and cavorting happily around the plane on an airstrip on Newfoundland. One is never quite sure to what extent this protagonist is to be taken seriously, if at all.

The ironic complexities of Bellow's view of Reich reveal the fascination that the latter's work and personality has held for the novelist. He is sympathetic toward Reich as a psychological and social revolutionary, one whose disaffection with bourgeois society can easily be shared by the author, who himself was an ardent socialist in his youth. At the same time, Bellow is sceptical towards Reich's belief in vegetotherapy as a means of regenerating the individual psyche. True rebirth or salvation remains an elusive goal in Bellow's work, though many of his characters pursue it most diligently. The radical therapy of Reich, aiming as it does at complete emotional liberation of the human being, is ultimately regarded by Bellow as a form of Romanticism that is as likely to lead to self-absorption and delusion as to cure. The openness and emotional honesty pursued 
by someone like Reich clearly appeals to the author on one level, as is felt in his portrait of Tommy Wilhelm, but he is even more aware of the impractical and hopelessly idealistic aspects of the whole approach. Emotional outbursts will not solve economic and social problems, and therapeutic quests, however ardently pursued, will not eradicate human frailty. In his view of Reich, Saul Bellow appears to accept the diagnosis, the criticism of the mass neurosis of capitalism, but not the solution, the orgone therapy and its farreaching claims. Accordingly, Bellow decided to use a comic approach to the subject, and Henderson the Rain King became the ironic narrative of a character who is an apt symbol of modern man, a creature of a confused era where people tend to be lured into all sorts of esoteric pursuits in order to find the right way to live.

\section{NOTES}

1 'Reichianism in "Henderson the Rain King"', Criticism, XV (1973), 213.

2 Saul Bellow: In Defense of Man (London, 1971), p. 133.

3 Whence the Power? The Artistry and Humanity of Saul Bellow (Columbia, Missouri, 1974), p. 144.

4 The Function of the Orgasm and Character Analysis appeared in English in 1942 and 1945, respectively. In a review of Henderson the Rain King, Richard G. Stern furnishessome biographical evidence of Bellow's interest in Reich in a footnote where Stern mentions his personal acquaintance with Bellow and states that he feels"in" on "such genetic factors as Bellow's interest in Reich." "Henderson's Bellow," Kenyon Review, 21 (1959), 661.

5 See The Function of the Orgasm (London, 1961), p. 289.

w Seize the Day (London, 1957), p. 73. Subsequent quotations from the text are from this edition and have page references.

7 "It was my character analysis which introduced the basic concept that the character structure is ill, sick, while neurosis, the neurotic symptom is only an outgrowth of a general characterological condition." Reich Speaks of Freud, ed. Mary Higgins and Chester M. Raphael (New York, 1972), p. 77.

8 Henderson the Rain King: A Novel (London, 1960), p. 3. Subsequent quotations from the text are from this edition and have page references.

9 Wibhelm Reich and Orgonomy (Oslo, 1970), p. 29. 